This PDF is a selection from a published volume from the National Bureau of Economic Research

Volume Title: Risk Topography: Systemic Risk and Macro Modeling

Volume Author/Editor: Markus Brunnermeier and Arvind Krishnamurthy, editors

Volume Publisher: University of Chicago Press

Volume ISBN: 0-226-07773-X (cloth); 978-0-226-07773-4 (cloth); 978-0-226-09264-5 (elSBN)

Volume URL: http://www.nber.org/books/brun11-1

Conference Date: April 28, 2011

Publication Date: August 2014

Chapter Title: A Transparency Standard for Derivatives

Chapter Author(s): Viral V. Acharya

Chapter URL: http://www.nber.org/chapters/c12511

Chapter pages in book: (p. 83 - 95) 


\title{
A Transparency Standard for Derivatives
}

\author{
Viral V. Acharya
}

Derivatives exposures across large financial institutions often contribute to - if not necessarily create - systemic risk. During a crisis, lack of adequate understanding of such exposures often compromises regulatory ability to unwind an institution, inducing large-scale backstops and counterparty bailouts. It is often claimed - in spite of the massive assistance that was provided in this crisis to deal with derivatives exposures - that derivative contracts are well collateralized so that counterparty risk on derivatives exposures is not a significant issue. Documenting evidence that supports or refutes this claim beyond reasonable doubt is currently infeasible due to the poor quality - and lack of standardization — of derivatives disclosures by financial firms. Nevertheless, all available evidence points against the claim that counterparty risk in derivative exposures is always well collateralized.

In many important cases that contributed to the crisis, most notably but not exclusively the case of AIG Financial Products, collateralization was weak. ${ }^{1}$ Some reports also suggest that the problem is probably of nontrivial magnitudes and that going forward derivatives exposures are likely to remain

Viral V. Acharya is the C. V. Starr Professor of Economics at the Stern School of Business at New York University and a research associate of the National Bureau of Economic Research.

This chapter is partly based on the chapter "Regulating OTC Derivatives," coauthored with Or Shachar and Marti G Subrahmanyam, in the book Regulating Wall Street: The Dodd-Frank Act and the New Architecture of Global Finance (NYU Stern and John Wiley \& Sons, November 2010). The author is grateful to Melissa Johnston and John Yan for research assistance and comments from Or Shachar and participants at the NBER conference of the Measuring Systemic Risk Initiative (October 2010). For acknowledgments, sources of research support, and disclosure of the author's material financial relationships, if any, please see http://www .nber.org/chapters/c12511.ack.

1. For example, The Financial Crisis Inquiry Report, released in January 2011, reports: "In the housing boom, CDS were sold by firms that failed to put up any reserves or initial collateral or to hedge their exposure. In the run-up to the crisis, AIG, the largest US insurance company, 
a potentially important contributor to systemic risk. For instance, using information from the 10-Q quarterly statements, the International Monetary Fund (IMF) reports estimate that the five key institutions that are active in the over-the-counter (OTC) derivatives market - Goldman Sachs, Citigroup, J.P. Morgan, Bank of America, and Morgan Stanley-were jointly carrying almost $\$ 500$ billion in OTC derivative payables exposure as of 3Q09. ${ }^{2}$ The report also estimates that the five largest European banksDeutsche Bank, Barclays, UBS, Royal Bank of Scotland (RBS), and Credit Suisse-had about $\$ 600$ to $\$ 700$ billion in undercollateralized risk (measured by residual derivative payables) as of December 2008. This residual exposure arises for two reasons, as per the IMF report. First, sovereigns, as well as AAA-rated insurers, corporations, large banks and multilateral institutions "do not post adequate collateral since they are viewed by large complex financial institutions as privileged and (apparently) safe clients." Second, dealers have agreed in their bilateral contracts not to mandate adequate collateral for dealer-to-dealer positions whereby creditworthy dealers often post no collateral to each other for these contracts.

These reports raise several pertinent questions:

- What is the true potential exposure on derivatives dealings of large institutions?

- How much of this exposure is collateralized?

- Is the collateral posted adequate under some conservative requirements of maximum counterparty risk in case of system-wide stress when besides the emergence of counterparty risk, positions become illiquid, hard to replace, and may have to be unwound at short notice?

- Are derivatives being deployed in an undercollateralized manner to undertake significant maturity transformation and taking on attendant liquidity risks? ${ }^{3}$

The chapter addresses these questions by examining the theoretical justification for a transparency standard for derivatives positions. To demonstrate that such a standard is implementable, the chapter shows examples of existing disclosures from large dealer firms in their quarterly filings. These disclosures often contain useful firm-level data on derivatives, but due to a lack of standardization, these are not aggregation friendly for assessing the risk to the system. The chapter highlights the important role for tracking of

would accumulate a one-half trillion dollar position in credit risk through the OTC market without being required to post one dollar's worth of initial collateral or making any other provision for loss. AIG was not alone."

2. Singh (2010).

3. In terms of "risk topography," derivatives can be considered the mechanism to build contingent exposures - across states of nature and over time-which when not adequately collateralized or capitalized, lead to liquidity risk. Thus, derivatives facilitate complex forms of "liquidity mismatch," discussed in greater detail in chapter 7 of this volume by Markus Brunnermeier, Gary Gorton, and Arvind Krishnamurthy. 
a "margin coverage ratio" (MCR), namely the ratio of a derivatives dealer's cash (or liquidity, more broadly) to its contingent collateral or margin calls in case of a significant downgrade of its credit quality. Finally, the chapter discusses the implications of such a possible standard for the Office of Financial Research (OFR) to be set up under the Treasury as per the DoddFrank Act in the United States.

\subsection{Case for Regulatory and Market Disclosure of Standardized Derivatives Reports}

It is useful to understand theoretically the market failure in the provision of information in derivatives markets. Acharya and Engle (2009) and Acharya and Bisin (2010) formalize this idea under the notion of a "counterparty risk externality." 4

To illustrate the idea, suppose that counterparty A agrees to pay B. Then, A turns around and sells a similar contract to $C$. The addition to A's position from the contract with $\mathrm{C}$ dilutes the payoff on its contract with $\mathrm{B}$ in the case that A turns out ex post to not have adequate funds to repay both $\mathrm{B}$ and C. Thus, B's payoff dependency on what else A does represents a negative payoff externality on B due to A's counterparty risk. The key efficiency question is whether B can adequately reflect this risk in charging price or adopting risk controls (e.g., margins or overall position limits) on A. Clearly, B's ability to do so depends upon whether B can observe what A does.

Now, if markets are organized over the counter (OTC) as with many derivatives contracts, there is opacity at the level of derivatives positions of a financial firm. As a result of this opacity, counterparty risk externality described earlier cannot be adequately reflected in price and collateral arrangements. More broadly, since generating information about each firm's derivatives positions requires its cooperation but benefits the system at large, the firm may not fully internalize the social benefits of transparency. This theory predicts, thus, that there will be too little production of private information in settings that involve counterparty risk externality. Acharya and Engle (2009) and Acharya and Bisin (2010) present several proposals to address this market failure.

One proposal is that central clearing and margining on exchanges get around this failure (at least when viewed in the realm of a particular clearinghouse or exchange). Central counterparty or trade-guaranteeing body or exchange can observe end-of-day (or even intraday) positions, and set position limits, concentration limits, and margin calls accordingly. This arrangement works best if the same clearing entity clears most products. Yet, many markets, especially for complex and customized derivatives, will almost necessarily remain OTC. They cannot easily be standardized if their 
primary purpose is to provide customized hedging to some end users, and the system may not find it profitable to incur transaction costs in setting up clearinghouses or exchanges for these products if their volumes are thin. For these remaining derivatives, some regulators have proposed addressing counterparty risk directly by limiting leverage (charging adequately high margin requirements) against them. Still, regulatory attempts to design such instrument-specific requirements have failed miserably in the design of capital requirements even on simpler instruments such as mortgages, loans, and lines of credit.

A second proposal, not necessarily exclusive of the first one, is to rely more on markets' transparency at large. Suppose information on the derivatives position of a financial firm was made available to market participants. This would enable better pricing and managing of counterparty risk by markets themselves. This way, dealers would be incentivized to lower their counterparty risks in an efficient manner. With a market-wide standard, dealers would also be incentivized to provide transparency about their own management of counterparty risk, a move that would benefit them the most in times of significant aggregate uncertainty when customers tend to leave business with riskier counterparties, triggering a "franchise value run," as witnessed by Goldman Sachs and Morgan Stanley around the collapse of Lehman Brothers, and instead "fly to quality."

A common argument against such public transparency of positions and counterparty level data is that it reduces the economic benefits of undertaking these positions in the first place and could reduce risk-sharing gains for the economy. A compromise would be to provide market transparency with a reasonable lag, so that price impacts for trading parties are minimized, and yet the lagged information is useful for counterparty risk assessments.

Finally, it is highly likely that an efficient transparency standard for derivatives will in turn produce an efficient information system at each financial firm that aggregates its own derivatives positions in different subsidiaries, markets, and countries. This could improve a firm's own risk management by providing timely information to senior management and chief risk officers about enterprise-wide risks.

\subsection{A Transparency Standard for Derivatives and Counterparty Risk}

What might a transparency standard for derivatives look like? Here is an example. All dealers, as well as large swap players, provide to a centralized data repository frequent (for example, weekly or biweekly) risk reports on their derivatives positions as follows:

Classification of exposures into

- product types (such as single-name CDS, index CDS, interest rate swaps, currency swaps, commodities, equities, etc.), 
- by major currency categories,

- maturity (buckets) of contracts,

- type of counterparty (bank, broker-dealer, corporation, governmentsponsored enterprise, monoline, insurance firm, etc.), and

- credit rating of counterparties.

Size of exposures could be reported as ${ }^{5}$

- gross (maximum notional exposure),

- in fair-value terms (to account for mark-to-market changes),

- net (taking account of bilateral netting arrangements), and

- uncollateralized net (recognizing collateral posted by counterparties).

Uncollateralized net exposures could be disclosed also as potential exposures based on stress tests ${ }^{6}$ that take account of

- several notches of ratings downgrade of a counterparty and its ability to post additional collateral, and

- counterparty default and replacement risk for the exposures assuming severe market conditions such as replacement time of two to four weeks. $^{7}$

To facilitate the understanding of contingent or potential exposures and for deriving implications for systemically risky exposures, all dealers, as well as large swap players, could also provide two important and novel reports:

Margin call reports that list the additional collateral liabilities of the firm as

- total additional liability in case the firm was to experience one, two, or more (say, up to six) notch downgrades, and

- largest such liabilities aggregated by different counterparties (say, ten largest).

Concentration reports that provide the above-mentioned information for the entity's largest counterparty exposures (say, the largest ten) or accounting for at least a substantial proportion (say, 75 percent) of the total exposure.

When aggregated across firms, the standardized firm-level reports aggre-

5. The crucial item here is "uncollateralized," as without knowledge of collateral backing the contracts, there is the risk of overstating the derivatives exposures, but more importantly, it would create the uncertainty about magnitude of risk in the first place.

6 . The focus of the standard considered here is on stress tests based on counterparty risk. Nevertheless, stress tests based on macroeconomic scenarios, as discussed in Darrell Duffie's chapter 3 in this volume, "Systemic Risk Exposures: A 10-by-10-by-10 Approach," could also be augmented to the standard.

7. In particular, the current disclosure of level 1, level 2, and level 3 of assets' underlying value might also be enhanced to report potential illiquidity and opacity of positions (not just for derivatives), so that an asset could be level 1 in normal times, but the disclosure would also state whether it is likely to be level 1 , level 2 , or level 3 in reasonable stress scenarios. 
Table 6.1 Outcome of the possible transparency standard for derivatives

\begin{tabular}{lllll}
\hline Disclosure & Firm 1 & Firm 2 & Firm $n$ \\
\hline Exposures & & & & \\
Product type & & & \\
Maturity bucket & & & \\
Counterparty type & & \\
Counterparty credit rating & & \\
Value & & & \\
Maximum loss (“potential exposure”) & & \\
Uncollateralized net & & \\
Net of collateral & & \\
By currency categories & & \\
Collateral posted & & \\
Margin Report: Additional collateral to post & & \\
One notch downgrade & & \\
Two-notch downgrade & & \\
Multinotch downgrade & & \\
Concentration Report: Firms, percentage of exposure & &
\end{tabular}

gate to a "map" of derivatives positions and their risks (mark-to-market risk, counterparty risk, and liquidity risk) as shown in table 6.1.

Although such a transparency standard appears at first to involve a large amount of information gathering, the costs of such disclosure are not likely to be that onerous. Sophisticated investment banks already maintain such information for their internal risk management purposes, and they do publish some of it in their quarterly reports (though in a highly nonstandardized and less granular manner, as explained later). Therefore, it is unlikely to be a significant additional burden for them to disclose such information to regulators in a standardized format at frequent intervals. Some aggregated versions that respect customer confidentiality can then be made transparent to markets at large, say on a monthly or at least quarterly basis, to help enhance market discipline against the buildup of uncollateralized exposures.

\subsection{What Do Financial Firms Currently Do and Do Not Disclose?}

The 10-Q filings of financial firms, as for any firms regulated by the Securities and Exchange Commission (SEC) in the United States, require disclosure of all materially relevant information. In case of financial firms, given their increasingly large presence in derivatives markets, these filings also contain information on positions - and on their risks - in these markets. A few examples to follow help illustrate what is useful in the current reports, and what changes would be necessary to adhere to a transparency standard such as the one outlined earlier. 
Consider for example the reporting of credit protection sold by Citigroup and J.P. Morgan Chase, shown from their 10-Q filings in tables 6.2 and 6.3. Citigroup reports its positions by industry, product, and credit rating of underlying reference entity, whereas J.P. Morgan reports them by maturity and credit rating of underlying entity. While it is possible to draw some relative conclusions about average credit rating of entities they write protection against (Citigroup wrote more risky protection than J.P. Morgan), other aspects of disclosures are not comparable. Nevertheless, the table reveals that financial firms could report these data in a standardized manner if required to do so.

Next, consider tables 6.4 and 6.5 that show Goldman Sachs and J.P. Morgan Chase's reporting of counterparty credit risk in their over-the-counter (OTC) derivatives positions. Goldman Sachs reports the positions as well as their value net of collateral by credit rating of counterparty, by risk types, and by maturity buckets. In this case, J.P. Morgan's reporting provides similar information as that of Goldman Sachs, facilitating a straightforward comparison. One can easily reach the conclusion that overall, in terms of percentage of overall exposures, J.P. Morgan's counterparty credit risk profile is safer than that of Goldman Sachs, as 40 percent of J.P. Morgan's OTC derivative credit exposure is with counterparties at a AA and higher level versus around 20 percent for Goldman Sachs.

Table 6.2 Citigroup's reporting of credit derivatives as protection seller

\begin{tabular}{lrr}
\hline $\begin{array}{l}\text { In millions of dollars as of } \\
\text { September 30, 2009 }\end{array}$ & $\begin{array}{c}\text { Maximum potential } \\
\text { amount of future payments }\end{array}$ & $\begin{array}{r}\text { Fair value } \\
\text { payable }^{\mathrm{a}}\end{array}$ \\
\hline By industry/counterparty & & \\
Bank & $\$ 860,437$ & $\$ 46,071$ \\
Broker-dealer & 301,216 & 17,661 \\
Monoline & - & 96 \\
Nonfinancial & 2,127 & 12,753 \\
Insurance and other financial institutions & 151,326 & $\$ 76,581$ \\
Total by industry/counterparty & $\$ 1,315,106$ & $\$ 76,383$ \\
By instrument & & 198 \\
Credit default swaps and options & $\$ 1,314,282$ & $\$ 76,581$ \\
Total return swaps & 824 & 23,362 \\
Total by instrument & $\$ 1,315,106$ & 33,231 \\
By rating & & 19,988 \\
Investment grade & $\$ 759,845$ & $\$ 76,581$ \\
$\quad$ Noninvestment grade & 422,865 & 132,396 \\
$\quad$ Not rated & $\$ 1,315,106$ & \\
Total by rating & & \\
\hline
\end{tabular}

Note: This table summarizes the key characteristics of the company's credit derivative portfolio as protection seller (guarantor) as of September 30, 2009.

${ }^{a}$ In addition, fair value amounts receivable under credit derivatives sold were \$23,324. 
Table 6.3

JPMorgan Chase's reporting of credit derivatives as protection seller (protection sold—credit derivatives and credit-linked notes ratings/maturity profiles ${ }^{\mathrm{a}}$ )

\begin{tabular}{lrrrrr}
\hline $\begin{array}{l}\text { December 31, 2008 } \\
\text { (in millions) }\end{array}$ & $<1$ year & $1-5$ years & $>5$ years & $\begin{array}{c}\text { Total } \\
\text { notional } \\
\text { amount }\end{array}$ & Fair value \\
\hline $\begin{array}{l}\text { Risk rating of reference entity } \\
\text { Investment grade } \\
(\text { AAA to BBB-) }\end{array}$ & $\$(177,404)$ & $\$(1,767,004)$ & $\$(713,555)$ & $\$(2,657,963)$ & $\$(215,217)$ \\
$\begin{array}{c}\text { Noninvestment grade } \\
(B B+\text { and below) }\end{array}$ & $(121,040)$ & $(992,098)$ & $(428,895)$ & $(1,542,033)$ & $(244,975)$ \\
\begin{tabular}{l} 
Total \\
\hline
\end{tabular} & $\$(298,444)$ & $\$(2,759,102)$ & $\$(1,142,450)$ & $\$(4,199,996)$ & $\$(460,192)$ \\
\hline
\end{tabular}

Note: This table summarizes the key characteristics of the company's credit derivative portfolio as protection seller (guarantor) as of December 31, 2008.

${ }^{a}$ The contractual maturity for a single-name CDS contract generally ranges from three months to ten years, and the contractual maturity for index CDS is generally five years. The contractual maturity for CLNs typically ranges from three to five years.

${ }^{b}$ Ratings scale is based upon the firm's internal ratings, which generally correspond to ratings defined by S\&P and Moody's.

${ }^{\mathrm{c}}$ Amounts are shown on a gross basis, before the benefit of legally enforceable master-netting agreements and cash collateral held by the firm.

Table 6.4

Goldman Sachs's reporting of OTC derivatives counterparty exposure

\begin{tabular}{lccrrcrrr}
\hline $\begin{array}{l}\text { Credit rating } \\
\text { equivalent }\end{array}$ & $\begin{array}{c}0-12 \\
\text { months }\end{array}$ & $\begin{array}{c}1-5 \\
\text { years }\end{array}$ & $\begin{array}{c}5-10 \\
\text { years }\end{array}$ & $\begin{array}{c}\text { years or } \\
\text { greater }\end{array}$ & \multicolumn{1}{c}{ Total } & Netting(b) & $\begin{array}{c}\text { Exposure } \\
\text { Exposure } \\
\text { net of } \\
\text { collateral }\end{array}$ \\
\hline AAA/Aaa & $\$ 1,482$ & $\$ 3,249$ & $\$ 3,809$ & $\$ 2,777$ & $\$ 11,317$ & $\$(5,481)$ & $\$ 5,836$ & $\$ 5,349$ \\
AA/Aa2 & 6,647 & 12,741 & 7,695 & 9,332 & 36,415 & $(20,804)$ & 15,611 & 11,815 \\
A/A2 & 31,999 & 46,761 & 29,324 & 31,747 & 139,831 & $(111,238)$ & 28,593 & 24,795 \\
BBB/Baa2 & 4,825 & 7,780 & 5,609 & 8,190 & 26,404 & $(12,069)$ & 14,335 & 8,041 \\
BB/Ba2 or & & & & & & & & \\
$\quad$ lower & 3,049 & 13,931 & 2,903 & 1,483 & 21,366 & $(5,357)$ & 16,009 & 9,472 \\
Unrated & 666 & 1,570 & 387 & 148 & 2,771 & $(224)$ & 2,547 & 1,845 \\
Total & $\$ 48,668^{\text {(a) }}$ & $\$ 86,032$ & $\$ 49,727$ & $\$ 53,677$ & $\$ 238,104$ & $\$(155,173)$ & $\$ 82,931$ & $\$ 61,317$ \\
\hline
\end{tabular}

Note: OTC derivative credit exposure (in millions) as of September 2009.

${ }^{a}$ Includes fair values of OTC derivative assets, maturing within six months.

${ }^{\mathrm{b}}$ Represents the netting of receivable balances with payable balances for the same counterparty across maturity categories and the netting of cash collateral received, pursuant to credit support agreements. Receivable and payable balances with the same counterparty in the same maturity category are netted within such maturity category, where appropriate.

Notably, no data on concentration of exposures in derivatives are currently revealed in any of the 10-Q filings. This creates a significant challenge in assessing systemic risk based on current public disclosures of financial firms.

In contrast, there is some useful information on potential margin calls. Table 6.6 illustrates that different financial firms report their margin liabili- 
JPMorgan Chase's reporting of OTC derivatives counterparty exposure

\begin{tabular}{|c|c|c|c|c|}
\hline \multirow{2}{*}{$\begin{array}{l}\text { Rating equivalent } \\
\text { December } 31 \\
\text { (in millions, except ratios) }\end{array}$} & \multicolumn{2}{|c|}{2008} & \multicolumn{2}{|c|}{2007} \\
\hline & $\begin{array}{c}\text { Exposure } \\
\text { net of all } \\
\text { collateral (\$) }\end{array}$ & $\begin{array}{l}\text { Percentage of } \\
\text { exposure net } \\
\text { of all collateral }\end{array}$ & $\begin{array}{c}\text { Exposure } \\
\text { net of all } \\
\text { collateral (\$) }\end{array}$ & $\begin{array}{l}\text { Percentage of } \\
\text { exposure net } \\
\text { of all collateral }\end{array}$ \\
\hline AAA/Aaa to $\mathrm{AA}-/ \mathrm{Aa} 3$ & 68,708 & 48 & 38,314 & 57 \\
\hline $\mathrm{A}+\mathrm{A} 1$ to $\mathrm{A}-/ \mathrm{A} 3$ & 24,748 & 17 & 9,855 & 15 \\
\hline $\mathrm{BBB}+/ \mathrm{Baa} 1$ to $\mathrm{BBB}-/ \mathrm{Baa} 3$ & 15,747 & 11 & 9,335 & 14 \\
\hline $\mathrm{BB}+/ \mathrm{Ba} 1$ to $\mathrm{B}-/ \mathrm{B} 3$ & 28,186 & 20 & 9,451 & 14 \\
\hline $\mathrm{CCC}+/ \mathrm{Caa} 1$ and below & 5,421 & 4 & 357 & - \\
\hline Total & 142,810 & 100 & 67,312 & 100 \\
\hline
\end{tabular}

Note: Ratings profile of derivative receivables MTM.

ties in the case of their own downgrades with varying levels of granularity and "stress." J.P. Morgan's report historically appears the best in a relative sense in that it includes margin liabilities for one-notch downgrade and up to six-notch downgrade. Goldman Sachs, however, reports margin liabilities only up to two notches, and the second notch is disclosed only since the crisis. It is immediately apparent from this report that J.P. Morgan's liquidity risk from one- to six-notch downgrade is far smaller in terms of multiplier on the required margin than it is for Goldman Sachs.

No discussion of contingent liquidity risk related to margin calls can be complete without a discussion of AIG. Table 6.7 shows that AIG reported only a one-notch downgrade risk up until 3Q 2008, and in that last quarter, reported up to two notches. From one to two notch, its collateral liability increased by a factor of six, a valuable piece of information in assessing the system's counterparty risk to AIG that was not available in their reports until 2Q 2008. ${ }^{8}$ As it turned out, while Moody's and Fitch downgraded it by two notches, Standard \& Poor's did so by three notches, resulting in collateral liability of $\$ 20$ billion, which was compounded upward eventually to

8. This information, too, was not available in a well-tabulated form in AIG's 10-Q of 3Q 2008, but in the body of the text: "Credit ratings are important to AIG's business, results of operations and liquidity. Downgrades in AIG's credit ratings could increase AIG's borrowing costs and could adversely affect its competitive position and liquidity. With respect to AIG's liquidity, it is estimated that, as of the close of business on April 30, 2008, based on AIGFP's outstanding municipal guaranteed investment agreements (GIAs) and financial derivative transactions at that date, a downgrade of AIG's longer-term senior debt ratings to 'Aa3' by Moody's Investors Service (Moody's) or 'AA-' by Standard \& Poor's, a division of the McGraw-Hill Companies (S\&P) would permit counterparties to call for approximately $\$ 1.8$ billion of collateral, while a downgrade to 'A1' by Moody's or A+ by S\&P would permit counterparties to call for approximately $\$ 9.8$ billion of additional collateral. Further downgrades could result in requirements for substantial additional collateral, which could have a material adverse effect on how AIGFP manages its liquidity. The actual amount of collateral that AIGFP would be required to post to counterparties in the event of such downgrades depends on market conditions, the fair value of outstanding affected transactions and other factors prevailing at the time of the downgrade. Additional obligations to post collateral would increase the demands on AIGFP's liquidity." 

Table 6.6 Contingent collateral liabilities for JPMorgan and Goldman Sachs collateral
(credit risk-related contingent features in derivates)

\begin{tabular}{|c|c|c|c|c|c|}
\hline & \multicolumn{3}{|c|}{ JP Morgan } & \multicolumn{2}{|c|}{ Goldman Sachs } \\
\hline & $\begin{array}{c}\text { Collateral } \\
\text { posted } \\
\text { (\$ billions) }\end{array}$ & $\begin{array}{c}\text { Additional } \\
\text { collateral } \\
\text { (\$ billions) in case } \\
\text { of downgrade } \\
\text { AA to BBB: } \\
6 \text { notch }\end{array}$ & $\begin{array}{c}\text { Additional } \\
\text { collateral } \\
\text { (\$ billions) in case } \\
\text { of downgrade } \\
\text { AA to AA-: } \\
1 \text { notch }\end{array}$ & $\begin{array}{l}\text { Additional } \\
\text { collateral } \\
\text { in case of } \\
\text { one-notch } \\
\text { downgrade } \\
\text { (\$ millions) }\end{array}$ & $\begin{array}{l}\text { Additional } \\
\text { collateral } \\
\text { in case of } \\
\text { two-notch } \\
\text { downgrade } \\
\text { (\$ millions) }\end{array}$ \\
\hline 2006-Q4 & 26.6 & & & & $\mathrm{n} / \mathrm{a}$ \\
\hline 2007-Q1 & 27.0 & 2.6 & 0.1 & 607.0 & $\mathrm{n} / \mathrm{a}$ \\
\hline 2007-Q2 & 28.3 & 2.9 & 0.2 & 598.0 & $\mathrm{n} / \mathrm{a}$ \\
\hline 2007-Q3 & 32.8 & 3.2 & 0.3 & 752.0 & $\mathrm{n} / \mathrm{a}$ \\
\hline 2007-Q4 & 33.5 & 2.5 & 0.2 & 595.0 & $\mathrm{n} / \mathrm{a}$ \\
\hline 2008-Q1 & 48.5 & 3.4 & 0.3 & 957.0 & $\mathrm{n} / \mathrm{a}$ \\
\hline 2008-Q2 & 58.2 & 3.5 & 0.6 & 785.0 & $\mathrm{n} / \mathrm{a}$ \\
\hline 2008-Q3 & 60.1 & 4.3 & 0.9 & 669.0 & $\mathrm{n} / \mathrm{a}$ \\
\hline 2008-Q4 & 99.1 & 6.4 & 2.2 & 897.0 & 2,140 \\
\hline 2009-Q1 & 82.3 & 4.9 & 1.4 & 941.0 & 2,140 \\
\hline 2009-Q2 & 67.7 & 4.0 & 1.2 & 763.0 & 1,930 \\
\hline 2009-Q3 & 66.0 & 4.4 & 1.5 & 685.0 & 1,700 \\
\hline 2009-Q4 & & & & & \\
\hline
\end{tabular}

Table 6.7 Contingent collateral liabilities of AIG (\$ millions)

\begin{tabular}{|c|c|c|c|c|}
\hline & $2007-1$ & $2007-2$ & $2007-3$ & $2007-4$ \\
\hline \multicolumn{5}{|l|}{ Marginal call reports } \\
\hline \multicolumn{5}{|l|}{ Additional collateral for } \\
\hline \multicolumn{5}{|l|}{$\begin{array}{l}\text { Additional collateral for } \\
\text { two-notch downgrade rating }\end{array}$} \\
\hline \multicolumn{5}{|l|}{ Additional collateral for } \\
\hline \multicolumn{5}{|l|}{ Additional collateral for } \\
\hline & $2008-1$ & $2008-2$ & $2008-3$ & Actual \\
\hline \multicolumn{5}{|l|}{ Marginal call reports } \\
\hline \multicolumn{5}{|l|}{ Additional collateral for } \\
\hline \multicolumn{4}{|l|}{ Additional collateral for } & Moody's and Fitch downgrade \\
\hline $\begin{array}{l}\text { Additional collateral for } \\
\text { three-notch downgrade rating }\end{array}$ & & & $-\$ 20,000$ & S\&P downgrade \\
\hline \multicolumn{5}{|l|}{ Additional collateral for } \\
\hline multinotch downgrade rating & & & $-\$ 32,000$ & Market risk adjustment \\
\hline
\end{tabular}


$\$ 32$ billion, given mark-to-market or fair-value adjustments due to deteriorating market conditions.

Finally, it is instructive to use these margin call reports in conjunction with the cash position of these firms to assess their margin coverage ratios (MCR). In 4Q 2008, J.P. Morgan Chase had cash-equivalent assets of \$26 billion, so that its MCR was over four, since its margin call for a sixnotch downgrade is $\$ 6.3$ billion. Goldman Sachs had cash assets (its "total global core excess") of over $\$ 100$ billion, giving it an MCR of around 50 for a margin call of $\$ 2.14$ billion at a two-notch downgrade. That is, while Goldman Sachs's liquidity risk due to collateral calls is substantial, it also holds a lot of unencumbered cash to deal with this risk. In contrast, AIG had cash assets of just around $\$ 2.5$ billion in 2008, giving it an MCR of between 1 and 2 for its $\$ 1.8$ billion margin call at one-notch downgrade. Once it revealed its two-notch downgrade risk in August 2008, its MCR for two-notch downgrade was just around 0.25 as its (hitherto undisclosed) margin call exposure was up at $\$ 9.8$ billion with a two-notch downgrade. AIG's margin risk was simply not well covered for a "stress" downgrade scenario by its holdings of cash assets. Importantly, for a multinotch downgrade, this was not at all transparent based on its 10-Q's prior to August 2008.

The purpose behind reporting these data from 10-Q filings is twofold. One, to make it clear that financial firms can, and do, report much of the possible standard discussed in this chapter for derivatives reporting. Second, to illustrate that standardized data can support and enhance the assessment of counterparty risk in derivatives markets using simple analytical tools such as the margin coverage ratio (MCR) that is analogous to the interest coverage ratio employed by credit rating analysts in their assessment of nonfinancial corporations' liquidity risk.

We now examine how a transparency standard like that described earlier would affect the degree to which the objectives of the recent financial reforms legislated in the United States could be achieved.

\subsection{Implications for the Dodd-Frank Reforms and the Office of Financial Research}

The "Wall Street Transparency and Accountability" part of the DoddFrank Act of 2010 requires that

- all existing derivative positions (both cleared and uncleared swaps) be reported to a swap data repository within 180 days of its enactment;

- all new positions - cleared or uncleared - be reported starting ninety days after the enactment (or an alternative legislated period);

- the repository be tasked with providing data to the regulatory agencies - including foreign and international agencies, if applicable - to minimize systemic risk; 
- the repository be tasked with publishing aggregate market information (trading and clearing in major swap categories, participants and developments in new products) to the public twice a year;

- there be real-time public reporting, meaning to report data relating to a swap transaction, including price and volume, as soon as technologically practicable after the time at which the transaction has been executed; and

- such public reporting, however, not include counterparty or customer information, and also have a delay exemption for "block trades" (to be defined by rule makers), taking account of the impact of disclosure of such trades on liquidity.

While these attempts to improve transparency in the derivatives markets are commendable, there are also several notable omissions:

- Prices of new trades are often not sufficient to mark old positions, since derivatives are often struck at terms so as to be at zero fair value to both involved parties. It is essential to have for derivative trades their potential exposure and collateral risk, not just current mark-to-market values. However, such risk management variables are not required by the act to be collected by a data repository. Indeed, there is no required reporting of collateral information of any trades, precluding analysis of potential counterparty risk.

- While clearinghouses will clearly collect required counterparty information for trades they clear and will (hopefully) set adequate initial and variation margins to counterparties, several complex derivatives positions will still remain OTC. Understanding the counterparty risk in these OTC positions is crucial for margining on clearinghouses as well as in broader assessments of credit risk and systemic risk.

- Legislating counterparty risk transparency for regulators may have some favorable effects. Extending such transparency in some lagged form to markets might help reinstitute market discipline as a buffer against regulatory failures to contain risks adequately.

All of these omissions can be addressed by a possible transparency standard, as explained in this chapter. ${ }^{9}$ Although there will remain private data repositories such as the Depository Trust and Clearing Corporation (DTCC), it is beyond doubt that over time the Office for Financial Research (OFR), which is required by the Dodd-Frank Act to be set up under the Treasury for collecting, analyzing, and disseminating systemic risk-relevant information and early warnings, will require derivatives counterparty risk

9. Indeed, the current hedge-accounting standards could also be possibly employed to make it clear what proportion of the exposures are for hedging purposes and to account for hedging effects in reported values and risks of positions. 
information. An adequate, standardized, and self-reported but audited disclosure of derivatives positions and risks by the largest financial firms would be invaluable in such an exercise. The Financial Stability Oversight Council (FSOC), representing heads of regulatory agencies in the United States, formed as per the Dodd-Frank Act and charged with the task of identifying systemically important financial institutions (SIFIs) and regulating them, would also find such standardized reporting on derivatives of direct use as this would reveal information about which firms are currently-or potentially - too interconnected to fail. Academics, regulators, accounting boards, and derivatives dealers and large banks could come together to refine and implement the standard.

\subsection{Conclusion}

In summary, enhancing market discipline and regulatory intelligence about counterparty risk in derivatives markets likely requires a new transparency standard. This standard could be layered on top of the current quarterly disclosures of derivatives positions and risks by financial firms, but with a greater frequency for regulatory reports. Of particular importance is position-level transparency of large derivatives players, not just in a static sense, but also as potential exposure to stress scenarios, margin call exposure in case of their credit quality deterioration, and concentration exposure for assessment of systemic interconnections. Such transparency would facilitate tracking valuable counterparty risk indicators, most notably the margin coverage ratio (MCR) that compares a firm's cash position to its margin call exposure under stress scenarios.

\section{References}

Acharya, Viral V., and Alberto Bisin. 2010. "Counterparty Risk Externality: Centralized versus Over-the-Counter Markets." Working Paper, New York UniversityStern.

Acharya, Viral V., and Robert Engle. 2009. "Derivatives Trades Should All Be Transparent." Wall Street Journal, May 15.

Singh, Manmohan. 2010. "Collateral, Netting and Systemic Risk in the OTC Derivatives Market.” IMF Working Paper 10/99, International Monetary Fund, Washington, DC. 